\title{
REVISED MODEL OF ATTENUATION OF ELECTROMAGNETIC WAVES DUE TO RAIN*
}

\author{
S. Tamošiūnas ${ }^{\text {a,b }}$, M. Žilinskas ${ }^{\text {a,c }}$, M. Šileika ${ }^{a}$, and M. Tamošiūniené ${ }^{d}$ \\ ${ }^{a}$ Faculty of Physics, Vilnius University, Saulètekio 9, LT-10222 Vilnius, Lithuania \\ E-mail: stasys.tamosiunas@ff.vu.lt \\ ${ }^{\mathrm{b}}$ Institute of Materials Science and Applied Research, Vilnius University, Saulètekio 9, LT-10222 Vilnius, Lithuania \\ ${ }^{\mathrm{c}}$ Communications Regulatory Authority of the Republic of Lithuania, Department of Radio Communication, Algirdo 27, \\ LT-03219 Vilnius, Lithuania \\ ${ }^{\mathrm{d}}$ Semiconductor Physics Institute, A. Goštauto 11, LT-01108 Vilnius, Lithuania
}

Received 18 November 2006

\begin{abstract}
The values of the rain rates were calculated by using a new revised model. The obtained values of rain rates were compared with the ITU-R (International Telecommunication Union - Radio Regulations) value ascribed to Lithuania and with ones measured in the Lithuanian Weather Stations. The dependences of rain attenuation on the frequency for three locations of Biržai, Vilnius, and Kaunas have been calculated by using the values of the rain rates $R$ obtained here and the ITU-R value. The dependence of rain attenuation on the frequency for Biržai has been calculated by using the value of rain rate obtained using Chebil's model as well. The suspicion that ITU-R value of $R_{0.01 \%}$ is too low, described in previous paper, has been confirmed by the data presented here.
\end{abstract}

Keywords: electromagnetic radiation, rain attenuation, rain rate

PACS: 41.20.Jb, 84.40.-x

\section{Introduction}

The electromagnetic waves propagating in atmosphere are attenuated due to their scattering and absorption by rain, snow, ice particles, fog, and clouds. The electromagnetic waves attenuation due to rain medium is one of the most important factors when analysing the wave propagation at frequencies of $10 \mathrm{GHz}$ and higher [1].

It is mentioned in [2] that the attenuation due to absorption is larger than attenuation due to scattering for wavelengths that are small compared with the drop size. For wavelengths that are great compared to drop size, the attenuation due to scattering is greater than attenuation due to absorption. The drop sizes are coupled with the rain rate $R$ [3]. The prediction of rain rate is the most important step when analysing rain attenuation [4]. Although the rain rate is presented in millimetres per hour $(\mathrm{mm} / \mathrm{h})$, an important parameter is the integration time, i.e. the time between readings of the rainfall [2]. An integration time of 1 minute was

\footnotetext{
* The report presented at the International Conference "Radiation interaction with Material and its Use in Technologies 2006", 28 30 September 2006, Kaunas, Lithuania.
}

used in [5]. In [6], an integration time of 5 minutes was used.

Rainfall rate is highly variable, both in terms of location and time [4]. Therefore the rain rate and attenuation due to rain are analysed for concrete climate conditions [4], [6-8]. In [2], it was concluded that ITU-R (International Telecommunication Union - Radio Regulations) proposed data is not suitable for microwave line planning in Latvia. It is worth to mention that the territory of Latvia is in ITU-R rain zone $E$ [2] and it is in the same rain zone as the territory of Lithuania. In [9], we presented the prediction of rain rate using local thunderstorm rainfall data. The obtained results showed that the values of rain rates vary starting from 43.9 up to $69.7 \mathrm{~mm} / \mathrm{h}$ in different locations of Lithuania.

In previous publication [4], we presented the calculations of rain rates and attenuation due to rain at Lithuanian climatic conditions. According to the local peculiarities of climatic conditions the change in Chebil's model [5] was made. It has been mentioned in [4] that the ITU-R value of $R_{0.01 \%}=22 \mathrm{~mm} / \mathrm{h}$ [10] attributed to Lithuania does not describe correctly 
Table 1 . The values of rain rates $R(\mathrm{~mm} / \mathrm{h})$ for $0.01 \%$ of time measured in Lithuanian Weather Stations (Biržai, Vilnius, and Kaunas) in the period of years 1999-2004.

\begin{tabular}{ccccccc}
\hline Locality & 1999 & 2000 & 2001 & 2002 & 2003 & 2004 \\
\hline Biržai & 71.9 & 38.6 & 59.8 & 38.9 & 23.9 & 40.1 \\
Vilnius & 45.5 & 46.7 & 35.7 & 26.8 & 23.1 & 33.2 \\
Kaunas & 31.4 & 27.9 & 45.1 & 30.8 & 38.6 & 35.9 \\
\hline
\end{tabular}

enough the Lithuanian climatic conditions and there is a need to specify this rain zone designation.

The main goals of this paper were to analyse the data of rainfall measured in the Lithuanian Weather Stations, to compare it with ITU-R value $R_{0.01 \%}=$ $22 \mathrm{~mm} / \mathrm{h}$ [10] and with the one calculated by using a new revised model, and to numerically determine the specific rain attenuation as well.

\section{The analysis of the rainfall data measured in the Lithuanian Weather Stations}

We analysed the rainfall data measured in the Lithuanian Weather Stations in the period starting from year 1999 up to year 2004. The integration time was ten minutes. The values of rain rates for $0.01 \%$ of time measured in Biržai, Vilnius, and Kaunas are presented in Table 1.

The data presented in Table 1 shows that the values of $R_{0.01 \%}$ in Biržai vary from $23.9 \mathrm{~mm} / \mathrm{h}$ in 2003 up to $71.94 \mathrm{~mm} / \mathrm{h}$ in 1999 . These values are up to $65 \%$ higher than that recommended by ITU-R for calculation of the rain attenuation. The value of $R_{0.01 \%}$ in Vilnius varies from $23.14 \mathrm{~mm} / \mathrm{h}$ in 2003 up to $46.74 \mathrm{~mm} / \mathrm{h}$ in 2000 . These values are up to $46 \%$ higher than the one recommended by ITU-R. The value of $R_{0.01 \%}$ in Kaunas varies from $27.9 \mathrm{~mm} / \mathrm{h}$ in 2000 up to $45.1 \mathrm{~mm} / \mathrm{h}$ in 2001 . The values of $R_{0.01 \%}$ obtained by averaging the data of rain rates presented in Table 1 are: $45.5 \mathrm{~mm} / \mathrm{h}$ in Biržai, $35.2 \mathrm{~mm} / \mathrm{h}$ in Vilnius, and $35 \mathrm{~mm} / \mathrm{h}$ in Kaunas. Even the average value of $R_{0.01 \%}$ in Biržai is by $51 \%$ higher than ITU-R value $R_{0.01 \%}=$ $22 \mathrm{~mm} / \mathrm{h}$. And the average values of $R_{0.01 \%}$ in Vilnius and Kaunas are by $37 \%$ higher than this ITU-R value. The suspicion that ITU-R value of $R_{0.01 \%}$ is too low, expressed in [4], is confirmed by the data presented in Table 1.

\section{A new model for estimation of the $R_{0.01 \%}$ value}

It was concluded in [4] that investigation of meteorological data shows the necessity to modify Chebil's
Table 2. The values of average rain rates $R(\mathrm{~mm} / \mathrm{h})$ for $0.01 \%$ of time measured in Biržai, Vilnius, and Kaunas (in the period of years 1999-2004), the values of rain rates $R^{\prime}(\mathrm{mm} / \mathrm{h})$ for $0.01 \%$ of time calculated by using Chebil's model [5], and the values of rain rates $R^{\prime \prime}$ $(\mathrm{mm} / \mathrm{h})$ for $0.01 \%$ of time calculated by using modified Chebil's model [4].

\begin{tabular}{cccc}
\hline Locality & $R, \mathrm{~mm} / \mathrm{h}$ & $R^{\prime}, \mathrm{mm} / \mathrm{h}$ & $R^{\prime \prime}, \mathrm{mm} / \mathrm{h}$ \\
\hline Biržai & 45.5 & 82.5 & 70.9 \\
Vilnius & 35.2 & 83.5 & 73.5 \\
Kaunas & 35.0 & 85.6 & 71.8 \\
\hline
\end{tabular}

model. The comparison of values of rain rates measured in Biržai, Vilnius, and Kaunas in the period from 1999 till 2004 with the values calculated by using Chebil's model [5] and with the values numerically obtained by using improved model [4] confirmed this conclusion (Table 2).

The values of rain rates determined by using Chebil's model [5] are higher by $58.1 \%$ (in Kaunas) up to $93.3 \%$ (in Biržai) than the average values measured over the period of years 1999-2004 (Table 2). The values of rain rates calculated by using the improved model [4] are from $35.8 \%$ (in Biržai) up to $52.1 \%$ (in Vilnius) higher than the average values measured over the period of years 1999-2004 (Table 2).

In [5], the rain rate value for $0.01 \%$ was expressed as

$$
R_{0.01 \%}=\alpha M^{\beta},
$$

where $\alpha=12.2903, \beta=0.2973, M$ is the average annual precipitation.

This relation was modified in [4]:

$$
R_{0.01 \%}=\alpha(\gamma M)^{\beta},
$$

where $0 \leq \gamma \leq 1.0$ is the coefficient of a warm period of the year.

According to the data of Lithuanian Weather Stations collected in the period from 1999 up to 2004, a new revised model for the rain rate estimation was obtained. The review of results measured in Lithuanian Weather Stations (see Table 1) shows that the relation between $R_{0.01 \%}$ and the annual precipitation can be written as

$$
R_{0.01 \%}=a(\gamma M)^{0.4},
$$

where $\gamma=0.6$; the coefficient $a=4.00$ in Biržai, $a=$ 3.23 in Vilnius, and $a=3.32$ in Kaunas.

The values of $R_{0.01 \%}$ calculated by using the relation (3) are: $R_{0.01 \%}=44.2 \mathrm{~mm} / \mathrm{h}$ in Biržai, $R_{0.01 \%}=$ $34.9 \mathrm{~mm} / \mathrm{h}$ in Vilnius, and $R_{0.01 \%}=34.9 \mathrm{~mm} / \mathrm{h}$ in Kaunas. 


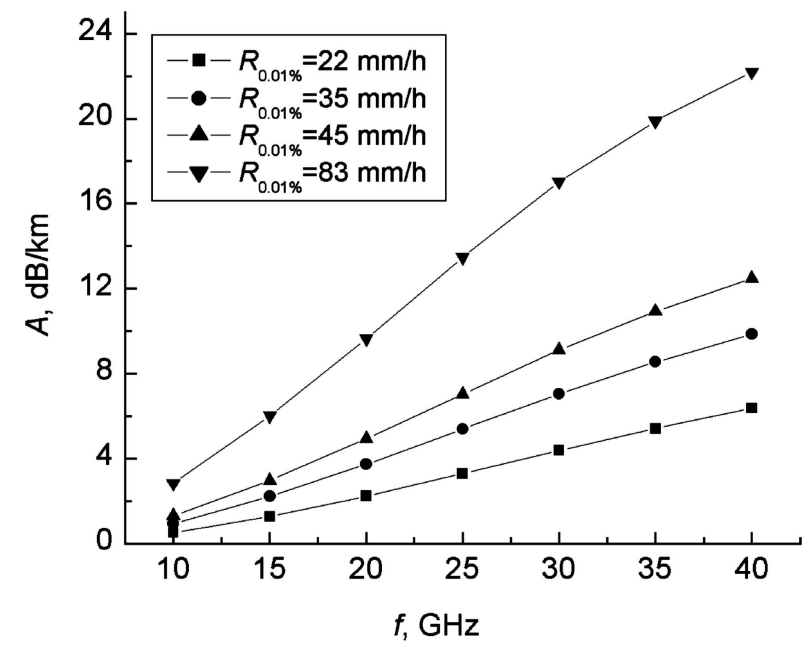

Fig. 1. Dependences of the specific rain attenuation $A$ on the radio signal frequency $f$ for different values of rain rates $R_{0.01 \%}$ (for horizontal polarization at a rain temperature of $20^{\circ} \mathrm{C}$ ).

One of the most widely accepted methods of dealing with excess path attenuation $A$ due to rainfall is an empirical procedure based on the approximate relation between $A$ and rain rate $R$ [1]:

$$
A=c R^{b}
$$

where $b$ and $c$ are functions on frequency $f$ and rain temperature $T$.

Considering the relation (3), Eq. (4) can be written as

$$
A=c\left[a(\gamma M)^{0.4}\right]^{b} .
$$

Relation (5) is a new model for the electromagnetic wave attenuation due to rain medium in atmosphere.

In [1], the values of $b$ and $c$ for horizontal polarizations are based on a rain temperature of $20^{\circ} \mathrm{C}$ and the Laws-Parson drop-size distribution. The dependences of specific rain attenuation $A$ on frequency $f$ for horizontal polarization at a rain temperature of $20^{\circ} \mathrm{C}$ have been calculated using Eq. 5 and the values of $b$ and $c$ have been taken from [1]. These dependences, numerically determined by using the rain rate values obtained for Biržai $\left(R_{0.01 \%}=45 \mathrm{~mm} / \mathrm{h}\right)$, Vilnius $\left(R_{0.01 \%}=\right.$ $35 \mathrm{~mm} / \mathrm{h})$, Kaunas $\left(R_{0.01 \%}=35 \mathrm{~mm} / \mathrm{h}\right)$, and the ITU-R value $R_{0.01 \%}=22 \mathrm{~mm} / \mathrm{h}$ [10], are presented in Fig. 1. The dependence of specific rain attenuation on frequency $f$ calculated by using the value $R=$ $83 \mathrm{~mm} / \mathrm{h}$ obtained for Biržai by using Chebil's model [5] and the specific attenuation dependence on frequency for rain rate $R=22 \mathrm{~mm} / \mathrm{h}$ (the ITU-R value) have been calculated and shown in Fig. 1 as well. In Biržai, the value of $A$ is higher by $5.8 \mathrm{~dB} / \mathrm{km}$ than the $A$ value obtained by using the ITU-R value $R_{0.01 \%}=$
$22 \mathrm{~mm} / \mathrm{h}$ and it is by $9.7 \mathrm{~dB} / \mathrm{km}$ higher than the one calculated by using the value $R_{0.01 \%}=83 \mathrm{~mm} / \mathrm{h} \mathrm{ob-}$ tained in Chebil's model when $f=40 \mathrm{GHz}$ (see Fig. 1). The values of specific rain attenuation in Vilnius and Kaunas are by $3.5 \mathrm{~dB} / \mathrm{km}$ higher than those calculated by using the ITU-R value of rain rate $R_{0.01 \%}=$ $22 \mathrm{~mm} / \mathrm{h}$ when $f=40 \mathrm{GHz}$.

\section{Conclusions}

New model for the electromagnetic wave attenuation due to rain medium in atmosphere has been presented for the first time. The suspicion that ITU-R value of $R_{0.01 \%}$ is too low, described in [4], has been confirmed by the experimental observation data presented in Table 1. There is a need to specify this value by using measured data of rain rates during a thirty year period. An integration time of 1 minute should be used for rain rate measurements.

The data presented here show that the value of specific rain attenuation in Vilnius is the same as in Kaunas.

\section{Acknowledgement}

The authors are grateful to the Direction of the Lithuanian Weather Station for the possibility to use the data of the Archives of the Weather Stations.

\section{References}

[1] R.L. Freeman, Radio System Design for Telecommunications (John Wiley \& Sons, Inc., New York, Chichester, Weinheim, Brisbane, Singapore, Toronto, 1997).

[2] G. Ivanovs and D. Serdega, Rain intensity influence on to microwave line payback terms, Electron. Electr. Eng. 6(70), 60-64 (2006).

[3] A. Ishimaru, Wave Propagation and Scattering in Random Media (Academic Press, New York, San Francisco, London, 1978).

[4] S. Tamošiūnas, M. Žilinskas, A. Nekrošius, and M. Tamošiūnienè, Calculation of radio signal attenuation using local precipitation data, Lithuanian J. Phys. 45(5), 353-357 (2005).

[5] J. Chebil and T.A. Raihman, Development of the oneminute rain rate contour maps for microwave applications in Malaysia peninsula, Electron. Lett. 35(20), 1772-1774 (1999).

[6] L.D. Emiliani, J. Agudelo, E. Gutierrez, J. Restrepo, and C. Fradique-Mendez, Development of rainattenuation and rain-rate maps for satellite system design in the Ku and Ka bands in Colombia, IEEE Antennas Propag. Mag. 46(6), 54-68 (2004). 
[7] A. Maitra, Rain attenuation modeling from measurements of rain drop size distribution in the Indian region, IEEE Antennas Wireless Propag. Lett. 3, 180181 (2004).

[8] R.K. Crane and D.V. Rogers, Review of the Advanced Communications Technology Satellite (ACTS) propagation campaign in North America, IEEE Antennas Propag. Mag. 40(6), 23-27 (1998).

[9] M. Zilinskas, S. Tamosiunas, and M. Tamosiuniene, Calculation of radio signal attenuation using annual precipitation and heavy rainfall data, in: 18th International Wroclaw Symposium and Exhibition on Electromagnetic Compatibility, Wroclaw, 28-30 June, 2006 (Wroclaw, Oficyna Wydawnicza Politechniki Wroclawskiej, 2006) pp. 490-493.

[10] Method for the determination of the coordination area around an earth station in frequency bands between $100 \mathrm{MHz}$ and $105 \mathrm{GHz}$, in: The ITU Radio Regulations, Appendices 7 to the Radio Regulations 2, 111206 (Geneva, 2004).

\title{
PATIKSLINTAS ELEKTROMAGNETINIŲ BANGŲ SILPNINIMO DE்L JŲ SAVEIKOS SU LIETUMI MODELIS
}

\author{
S. Tamošiūnas ${ }^{\text {a, b }}$, M. Žilinskas ${ }^{\text {a,c }}$, M. Šileika ${ }^{a}$, M. Tamošiūniené ${ }^{\mathrm{d}}$ \\ ${ }^{a}$ Vilniaus universiteto Fizikos fakultetas, Vilnius, Lietuva \\ ${ }^{\mathrm{b}}$ Vilniaus universiteto Medžiagotyros ir taikomuju mokslu institutas, Vilnius, Lietuva \\ ${ }^{\mathrm{c}}$ Lietuvos Respublikos Ryšiu reguliavimo tarnyba, Vilnius, Lietuva \\ ${ }^{\mathrm{d}}$ Puslaidininkiu fizikos institutas, Vilnius, Lietuva
}

\section{Santrauka}

Savitojo silpninimo, kurị lemia elektromagnetinès spinduliuotès sąveika su lietaus lašais, vertès yra lietaus intensyvumo funkcija. Lietaus intensyvumo vertès apskaičiuotos taikant Chebil'io modelio ir [4] darbo pagrindu sukurtą naują modeli, atsižvelgianti i Lietuvos Hidrometeorologijos tarnybos lietaus intensyvumo duomenis, išmatuotus 1999-2004 metais Vilniuje, Kaune ir Biržuose. Lietaus intensyvumo vertès, apskaičiuotos taikant naują modelį, palygintos su Tarptautinès Telekomunikacijų sajungos (ITU-R) rekomenduojama lietaus intensyvumo verte bei Lietuvos Hidrometeorologijos tarnybos išmatuotomis vertemis. Gauti rezultatai patvirtino [4] darbe pateiktą prielaidą, kad ITU-R duomenys, rekomenduojami naudoti Lietuvos Respublikos teritorijoje, netiksliai apibūdina jos gamtines sąlygas. Pasinaudojus gautomis lietaus intensyvumo vertemis Biržuose, Kaune ir Vilniuje (dvi pastarosios vertès beveik sutapo) bei ITU-R rekomenduojama lietaus intensyvumo verte, apskaičiuotos savitojo silpninimo priklausomybès nuo signalo dažnio, kai elektromagnetinė banga buvo horizontaliai poliarizuota, o aplinkos temperatūra buvo $20^{\circ} \mathrm{C}$. Nustatyta, kad savitojo silpninimo vertè Biržuose, kai dažnis $f=40 \mathrm{GHz}$, yra $5,3 \mathrm{~dB} / \mathrm{km}$, o Vilniuje $2,7 \mathrm{~dB} / \mathrm{km}$ didesné nei vertè, gauta pasinaudojus ITU-R verte $R_{0,01 \%}=22 \mathrm{~mm} / \mathrm{h}$. Palyginimui pateikta savitojo silpninimo priklausomybė nuo dažnio, apskaičiuota naudojant lietaus intensyvumo vertę Biržuose, gautą taikant Chebil'io modelį. 